\title{
Strategies of Stranger Inclusion in the Narrative Traditions of Joshua-Judges: The Cases of Rahab's household, the Kenites and the Gibeonites ${ }^{1}$
}

\author{
Péter Jenei (University of Pretoria)
}

\begin{abstract}
Ancient Israelite thought - represented by biblical Hebrew terminology - is aware of the difference between a non-assimilated stranger (נָכָך /

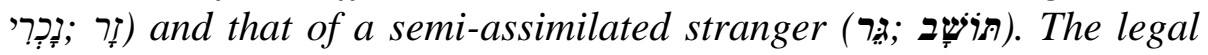
traditions of the OT are rather static and categorical regarding the differentiation of these types of strangers; they minimize the relationship with the ריפרים In addition, the law codes are almost exclusively silent about the possibility of a certain stranger's transition from one category to the other. Contrary to this, the narrative accounts of the OT are especially rich in representations of distinct strategies of stranger inclusion. Thus, it is evident that the ancient Israelite thought and everyday practice did not exclude the possibility of transitioning and transforming complete strangers into community members. In fact, the narrative representations of the treatment of strangers in the Books of Joshua and Judges encapsulate authentic ancient Israelite mentalities, cultural conventions, and social mechanisms - in a quite dynamic manner (cf. Rahab's inclusion in Josh 2 and 6; the Kenites' status in Judg 4-5; the Gibeonites' inclusion in Josh 9).
\end{abstract}

KEYWORDS: stranger; stranger inclusion; law; narrative; Rahab; Kenites; Gibeonites; Joshua-Judges.

* Submitted: 28/11/2018; peer-reviewed: 30/12/2018; accepted: 24/01/2019. Péter Jenei, "Strategies of Stranger Inclusion in the Narrative Traditions of Joshua-Judges: The Cases of Rahab, the Kenites, and the Gibeonites," Old Testament Essays 32 no. 1 (2019): 127-154. DOI: https://doi.org/ 10.17159/2312-3621/2019/v32n1a8

1 The present study is an edited and reworked version of the paper presented in the EABS unit, "Anthropology and the Bible", at the 2017 international SBL/EABS joint meeting. Berlin, Humboldt University, August 7-11, 2017. I would like to express my gratitude to the unit leaders, Emanuel Pfoh and Anne Katrine Gudme for their invaluable comments during the sessions. 


\section{A INTRODUCTION: THE CONCEPT OF "OTHERNESS" AND "STRANGENESS" IN THE OT}

Through defining the other, a group determines what it is not; in short, it establishes its boundaries. The other is, therefore, an essential component of any group's project of self-definition. ${ }^{2}$

The designation of "us" and "them" played a significant role in ancient Israelite thought; the polarity of these ranges is well represented in the biblical Hebrew terminology. The Israelites understood themselves as "the sons of

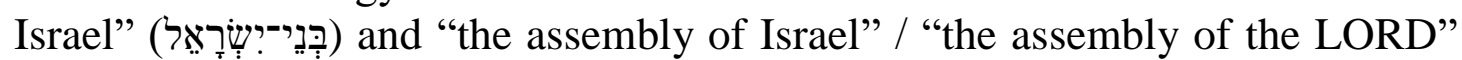

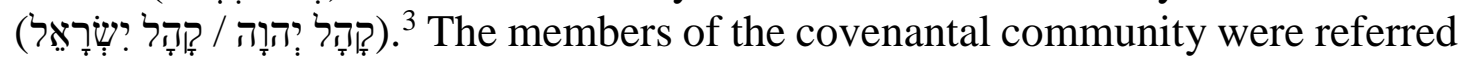

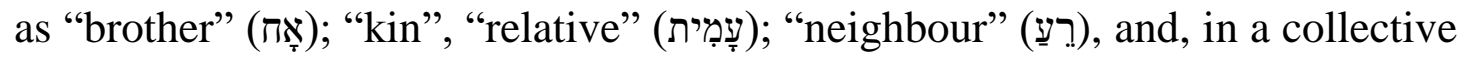

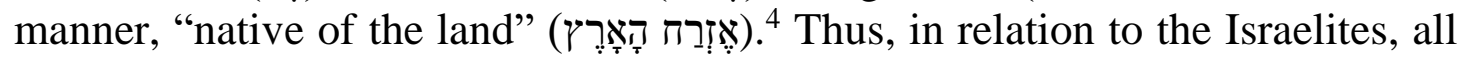
non-Israelites, foreigners, and outsiders were regarded as "others" and "strangers". However, the ancient Israelite understanding of strangeness reflected in the biblical Hebrew terminology is aware of the difference between

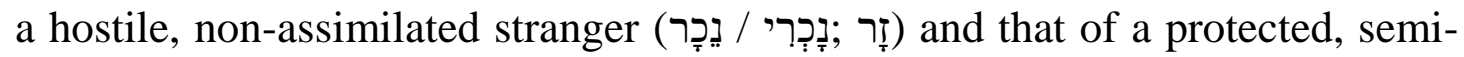

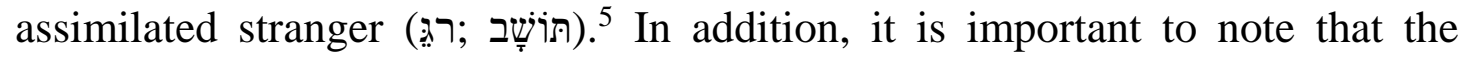
definition of otherness in ancient Israel was not primarily an ethnic, but rather a cultural-political and cultic-religious concern. Thus, otherness and strangeness in ancient Israel were defined by being uncircumcised, being unclean, having strange customs, and worshipping strange gods.

To denote strangeness and otherness in general, the biblical Hebrew

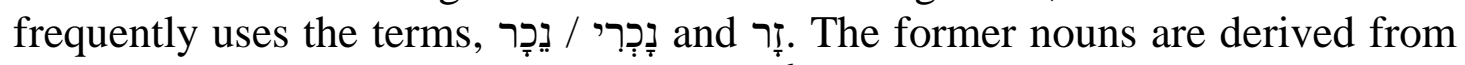
the root, נכר (I), meaning "to be foreign". ${ }^{6}$ The latter noun is derived from the root, זוּר (II), meaning "to turn aside", "to go away". 7 In this sense, a large part of the Old Testament occurrences of נָכָָר den denote foreigners and the sons

2 Saul M. Olyan, Rites and Rank: Hierarchy in Biblical Representations of Cult (Princeton: Princeton University Press, 2000), 63.

3 Cf. Norman K. Gottwald, The Tribes of Yahweh. A Sociology of the Religion of Liberated Israel, 1250-1050 B.C.E. (Maryknoll, NY: Orbis, 1979), 239-44.

4 Cf. Josh Pedersen, Israel. Its Life and Culture (vols. I-II; London: Oxford University Press, 1926), 57-61.

5 The terminological and conceptual distinction of the strangers in the context of the Hebrew Bible has been recognized by scholars from the beginning. Cf. Alfred Bertholet, Die Stellung der Israeliten und der Juden $z u$ den Fremden (Basel/Freiburg/Leipzig: J. C. B. Mohr [Paul Siebeck], 1896), 2. Michael Guttmann, “The Term 'Foreigner' (נפרי) Historically Considered," HUCA 3 (1926): 1.

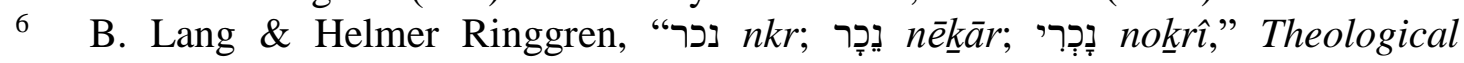
Dictionary of the Old Testament 9 (1998): 424.

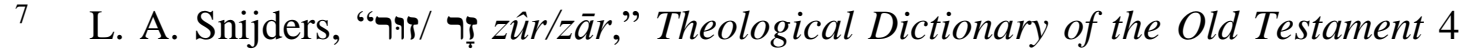
(1980): 52. 
of the other nations, ${ }^{8}$ and then the majority of the incidences of זָ denote foreign nations as hostile enemies. ${ }^{9}$ The feminine forms of both terms are particularly applied to the so-called strange women, who are either foreign women or the wives of other men. ${ }^{10}$ It is important to note that the biblical incidences of these terms may both signify the exogenous and the indigenous others, thus, the terms denote strangers, who persist in keeping politically and socially their original identity, distinct from the Israelites. ${ }^{11}$

To denote the act of sojourning and the phenomenon of permanent dwelling in the midst of a hosting community, the biblical Hebrew frequently

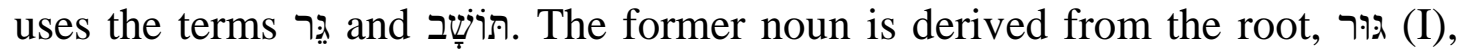
meaning "to tarry as a sojourner", "to dwell as a sojourner". ${ }^{12}$ According to Na'aman, the basic meaning of the root in the OT is to stay, temporarily or permanently, in a place which is not the original residence of someone who becomes a sojourner. It can denote residence in a foreign country, or in a new settlement within the borders of the country of origin, even not far from the person's birthplace. ${ }^{13}$ Spina provides a persuasive argument that the verbal usage predates the nominal usage. ${ }^{14}$ In addition, Ramírez Kidd highlights that the majority of the 81 incidences of the verbal form are predominantly found in OT narrative, prophetic, and wisdom literature. ${ }^{15}$ Furthermore, the OT narratives, besides גוג, make use of a combination of supporting verbs to describe the theme

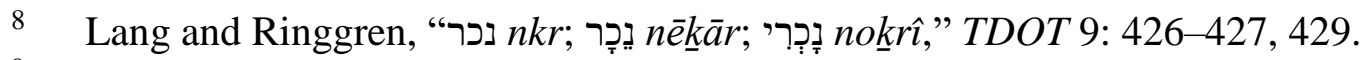

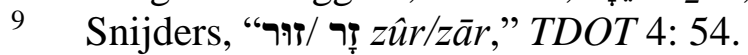

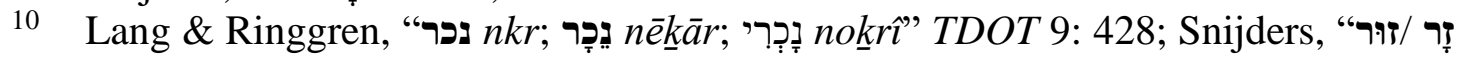
zûr/zār," TDOT 4: 56.

11 Pekka Pitkänen, "Ancient Israelite Population Economy: Ger, Toshav, Nakhri and Karat as Settler Colonial Categories," JSOT 42/2 (2017): 146-148.

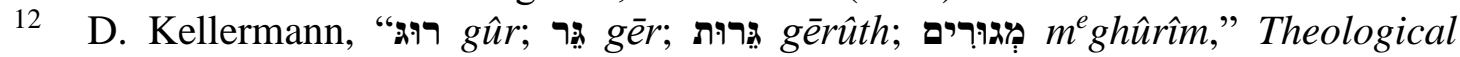
Dictionary of the Old Testament 2 (1975): 439. Following Kellermann, it is rather interesting to note that the meaning of (II) is "to strike", "to attack", "to combat", "to struggle", and the meaning of (III) is "to fear", "to be frightened". Kellerman argues that these roots are connected and most possibly originate from one single root. Thus, it means that in ancient Israelite mind the phenomena of sojourning and immigration were deeply connected to fear, threat and struggle.

13 Nadav Na'aman, "Sojourners and Levites in the Kingdom of Judah in the Seventh Century BCE," ZAR 14 (2008): 240.

14 "[...] it can be established that the root in question was used in texts prior to the date of the settlement ... the Hebrew root is found in three early poems: Gen 49:9; Judg 5:17; Deut 33:22." Cf. Frank Anthony Spina, "Israelites as gērîm, 'Sojourners,' in Social and Historical Context, in The Word of the Lord Shall Go Forth: Essays in Honor of David Noel Freedman in celebration of his $60^{\text {th }}$ birthday (ed. C. L. Meyers \& M. P. O'Connor; ASOR Special Volume Series 1; Winona Lake: Eisenbrauns, 1983), 329.

15 Cf. José E. Ramírez Kidd, Alterity and Identity in Israel: The גר in the Old Testament (BZAW 283; Berlin/New York: Walter de Gruyter, 1999), 18, fn. 32. 
of sojourning and permanent dwelling. ${ }^{16}$ The root 1 is is used in relation to both men and women, thus, the non-gendered usage of the root highlights the neutral, genderless character of the experience of sojourning and permanent dwelling in the midst of another community.

On the basis of the verbal root, the nominal form denotes a certain resident - may it be an Israelite or non-Israelite -, who lives in the midst of the local Israelite community where he is accepted, protected and enjoys certain rights. 17 In this regard, the term denotes semi-assimilated strangers; they occupy an intermediate position between the local Israelites and the נִכְְרִים 18 According

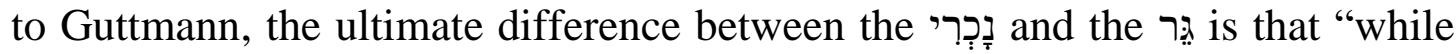
the גר thus seeks to become a member of the new community, the נכרי persists in keeping, politically and socially, his former status."19 In addition, according to Spina, "immigrant" may be an acceptable translation of the which translation calls attention to the original circumstances of social conflict which are inevitably responsible for small or large-scale withdrawal of people from their original social setting, and making them גammigrant in another.20 It is important to note that the term lacks the feminine form, thus, its use is restricted as a masculine noun in the OT, which, therefore, denotes a figurative legal status granted exclusively to the male head of the household. ${ }^{21}$

The noun תiֹשָׁב is derived from the root, meaning "to dwell", "to reside", therefore, the meaning of the term is "someone who dwells or resides", hence the תis is a dweller, a resident. ${ }^{22}$ The term occurs in historically late priestly texts of the OT and it seems somewhat interchangeable with the term ג. Kellermann argues that while the term denotes the legal status of the sojourner, the term sis could refer to the economic stand of the same person, thus, someone who is a landless protégé or client. ${ }^{23}$ However, Rendtorff argues that

16 (Gen 19:9; 35:27; 47:4; Deut 18:6; Judg 17:8, 9; 1Sam 21:11; 1Kgs 11:17; Ps 105:23; Jer 42:15, 17, 22; 43:2; 44:8, 12, 14, 28); ברח (Judg 9:21; 11:3; 1Sam 21:11; 27:4; 2Sam 4:3; 13:34; 1Kgs 11:17, 23, 40); הלך (Judg 9:21; 17:8, 9; Ruth 1:1; 2Kgs 8:1, 2); נרד (Gen 12:10; Deut 26:5; Isa 52:4); נוס (Josh 20,9; Judg 9:21); נסע (Gen 11:2; 12:9; 13:11; 20,1; 33:17; 35:21; 46:1); ישב (Gen 20,1; 47,4; Josh 6:25; Judg 9:21; 5:17; Jer 35:7; 44:14; 49:18, 33; 50:40); שכן (Judg 5:17; Ps 50:1; 120:5). Cf. Ramírez Kidd, Alterity and Identity, 13-14.

17 Roland de Vaux, Ancient Israel: Its Life and Institutions (The Biblical Resource Series; Grand Rapids: Eerdmans, 1997), 74.

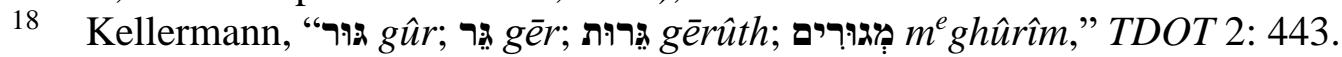

19 Guttmann, "The Term 'Foreigner'," 1. Cited by Hans-Georg Wuench, "The Stranger in God's Land - Foreigner, Stranger, Guest: What Can We Learn from Israel's Attitude towards Strangers?" OTE 27/3 (2014): 1150.

20 Cf. Spina, "Israelites as gērîm," 323.

21 Cf. Ramírez Kidd, Alterity and Identity, 16, 28.

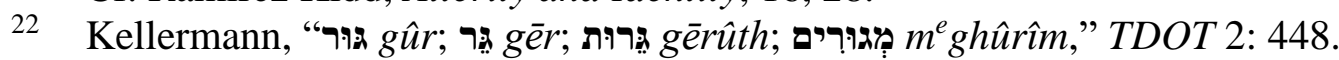

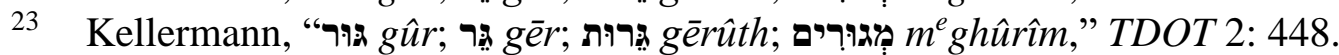


there must be some minor distinction between them because according to the

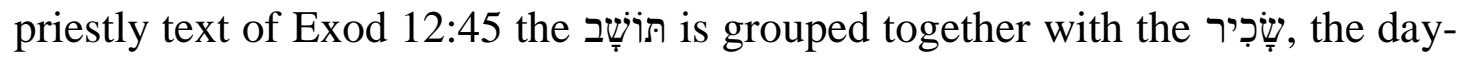
labourer, and they both cannot participate in the Passover, while a bit later in the text, in Exod 12:48, the 1 is allowed to participate. Therefore, it seems that the social and cultic integration of the was more advanced than of the ${ }^{24}$

To conclude, on the basis of the OT's "continuum of categories" 25 from native to foreigner, it is possible to understand the advanced concept of otherness and strangeness in ancient Israelite thought. The various accounts also shed light on the differentiated treatment of these distinct groups of strangers.

\section{B AIM AND RELEVANCE OF THE PRESENT STUDY}

When considering the history of research of the status and treatment of strangers in OT literature and culture, it is striking that until recently this special field was overly concentrating on the solid nominal terms and the legal treatment of the strangers in the Pentateuch, ${ }^{26}$ meanwhile, due to their uncertain origin and dating, the narrative representation of the status and treatment of strangers - except for

24 Rolf Rendtorff, "The gēr in the Priestly Laws of the Pentateuch," in Ethnicity and the Bible (ed. Mark G. Brett; BibInt Series 19; Leiden/New York/Köln: E. J. Brill, 1996), 79.

25 Cf. the phrasing of Pitkänen, “Ancient Israelite Population Economy,” 141.

26 The statement is true for the majority of the monographs in the field: Christiana van Houten, The Alien in Israelite Law (JSOTSup 107; Sheffield: Sheffield Academic Press, 1991); Christoph Bultmann, Der Fremde im antiken Juda: eine Untersuchung zum sozialen Typenbegriff "gēr" und seinem Bedeutungswandel in der alttestamentlichen Gesetzgebung (FRLANT 153; Göttingen: Vandenhoeck \& Ruprecht, 1992); Harold V. Bennett, Injustice Made Legal: Deuteronomic Law and the Plight of Widows, Strangers, and Orphans in Ancient Israel (Grand Rapids/Cambridge: Eerdmans, 2002); Reinhard Achenbach, Rainer Albertz \& Jakob Wöhrle, ed., The Foreigner and the Law: Perspectives from the Hebrew Bible and the Ancient Near East (BZAR 16; Wiesbaden: Harrassowitz Verlag, 2011); Ruth Ebach, Das Fremde und das Eigene: Die Fremdendarstellungen des Deuteronomiums im Kontext israelitischer Identitätskonstruktionen (BZAW 471; Berlin: Walter de Gruyter, 2014); Mark A. Awabdy, Immigrants and Innovative Law: Deuteronomy's Theological and Social Vision for the גר (FAT 2/67; Tübingen: Mohr Siebeck, 2014). Mark R. Glanville, Adopting the Stranger as Kindred in Deuteronomy (Ancient Israel and Its Literature 33; Atlanta: SBL Press, 2018). More comprehensive, but still Pentateuch-oriented monographs in the field include: Alfred Bertholet, Die Stellung der Israeliten und der Juden zu den Fremden (Basel/Freiburg/Leipzig: J. C. B. Mohr [Paul Siebeck], 1896); José E. Ramírez Kidd, Alterity and Identity in Israel: The גר in the Old Testament (BZAW 283; Berlin/New York: Walter de Gruyter, 1999); Markus Zehnder, Umgang mit Fremden in Israel und Assyrien: Ein Beitrag zur Anthropologie des »Fremden « im Licht antiker Quellen (BWANT 168; Stuttgart: Kohlhammer, 2005); Volker Haarmann, JHWH-Verehrer der Völker: Die Hinwendung von Nichtisraeliten zum Gott Israels in alttestamentlichen Überlieferungen (Zürich: Theologischer Verlag Zürich, 2008). 
the Book of Ruth and Ezra-Nehemiah ${ }^{27}$ - did not receive systematic and monographic attention. ${ }^{28}$ However, from the millennium onward, there seems to be a growing interest concerning the status and treatment of strangers in OT narratives. $^{29}$ Nevertheless, comprehensive studies on the narrative representations of the treatment of strangers in Joshua-Judges and SamuelKings are still small in numbers, although these corpora hold great potential concerning a dynamic representation of actual ancient Israelite relations to strangers. In addition, the various laws concerning the treatment of strangers only represent a static, ideal treatment, while the narrative texts - regardless of their late date and edited nature - encapsulate ancient customs and social mechanisms which are basically absent and/or differ in the figurative legal material. In fact, when analysing the narrative representations of the treatment of strangers in the Deuteronomic narrative accounts, it becomes clear, that on certain points they seem to contradict with the Deuteronomic legal treatment. Thus, the

27 For in-depth treatments of these fields, including history of research, see Katherine E. Southwood, Ethnicity and the mixed marriage crisis in Ezra 9-10 (Oxford Theological Monographs; Oxford: Oxford University Press, 2012); Christian Frevel, ed., Mixed marriages: Intermarriage and group identity in the Second Temple Period (HB/OT Studies 547; New York: T \& T Clark, 2011); Edward Allen Jones III, Reading Ruth in the Restoration Period: A Call for Inclusion (HB/OT Studies 604; New York: Bloomsbury, 2016).

28 Until the millennium, apart from the commentaries, predominantly journal articles and book chapters were concerned with the status and treatment of strangers based on narrative literature. Pioneering works include: A. H. van Zyl, "The Relationship of the Israelite Tribes to the Indigenous Population of Canaan according to the Book of Judges," in Studies on the Book of Judges: Papers read at 2rd meeting held at Potchefstroom, 2-5 February 1959 (Pretoria: OTWSA, 1959), 51-60, idem, "Israel and the Indigenous population of Canaan according to the Book of Samuel," in Studies on the Books of Samuel: Papers read at $3^{\text {rd }}$ meeting held at Stellenbosch, 26-28 January 1960 (Pretoria: OTWSA, 1960), 67-80. Spina, 'Israelites as gērîm, 'Sojourners,' in Social and Historical Context" (1983); Victor H. Matthews \& Don C. Benjamin, Social World of Ancient Israel. 1250-587 BCE (Peabody: Hendrickson Publishers, 1993), 5256.

29 Daniel Bodi, "Outraging the resident-alien: King David, Uriah the Hittite, and an El-Amarna parallel," UF 35 (2003): 29-56; Gary Stansell, "Wealth: How Abraham Became Rich," in Ancient Israel: The Old Testament in its Social Context (ed. Philip F. Esler; Minneapolis: Fortress Press, 2005), 92-110; Frank A. Spina: The Faith of the Outsider: Exclusion and Inclusion in the Biblical Story (Grand Rapids/Cambridge: Eerdmans, 2005); Nadav Na'aman, "David's Sojourn in Keilah in light of the Amarna Letters," VT 60 (2010), 87-97; Adriane Leveen, "Inside and Out: Jethro, The Midianites and a Biblical Conception of the Outsider," JSOT 34/4 (2010): 395-417; Elisabeth R. Kennedy, Seeking a Homeland. Sojourn and Ethnic Identity in the Ancestral Narratives of Genesis (BibInt Series 106; Leiden/Boston: Brill, 2011); Adriane Leveen, Biblical Narratives of Israelites and their Neighbours: Strangers at the Gate (Routledge Interdisciplinary Perspectives on Biblical Criticism; London: Routledge/Taylor \& Francis Group, 2017). 
Deuteronomic narratives in Joshua-Judges picture a different treatment toward strangers than the Deuteronomic laws. Therefore, the purpose of the present study is to analyse the dynamic, custom-like narrative representations concerning the treatment of strangers in Joshua-Judges. The projected outcome of the study is cultural and socio-historical in nature.

\section{ORIENTATION: LEGAL TREATMENT OF THE STRANGERS IN THE COVENANT CODE AND THE DEUTERONOMIC CODE}

A brief orientation of the legal treatment of the different types of strangers in the earlier Pentateuchal law codes (Covenant Code, Deuteronomic Code) is necessary to understand their formal status within ancient Israelite society.

Allusions to the non-assimilated strangers are rather sparse in the earlier law codes of the Pentateuch; in fact, there are only four direct references to the treatment of the נָכִרי in the Deuteronomic Code. Deut 17:15 is a prohibition against setting a foreign king over Israel. ${ }^{30}$ The rest of the references envision rigid commercial contacts with the נָכְרִ devoid of favours and privileges. Deut 15:1-3 grants a remission of debts in every seventh year for the fellow Israelites, but the debt of the strangers are still exacted. Deut 23:21 gives permission to charge interest on loans which were given to strangers. Finally, Deut 14:21 is the clearest example of the tripartite distinction within the ancient Israelite society: 1) it is prohibited for the fellow Israelites to consume the meat of an animal which died of itself; 2) however, as an act of charity, the meat could be given to the protected residents, the גֶרים, thus, it is permitted for them to eat this type of unclean meat; 3) as a final alternative, the meat could be sold to the נִכְרִים, i.e. it is permitted for Israelites to take advantage of the non-assimilated strangers.

It is important to note that the Code of Warfare (Deut 20) and its supplement (Deut 21:10-14) in the DC offer an indirect connection concerning the treatment of the נִכְר . Although the term does not occur in these texts, it is rather clear that the non-assimilated strangers are in mind. Concerning the exogenous others, of those, who are non-Canaanites, the text of Deut 20:10-15 envisions a twofold treatment: 1) if they surrender, then they could be subjected to forced labour; 2) if they resisted, then all the males could be put to the sword, and the women, children, and animals could be taken as booty. As a supplement, Deut 21:10-14 describes a detailed process of the cultural homogenization of war captive women. ${ }^{31}$ Concerning the indigenous others (i.e. the remnants of the

30 For an in-debt analysis, see Ernest Nicholson, "»Do not Dare to Set a Foreigner Over You. « The King in Deuteronomy and »The Great King«," ZAW 118 (2009): 4661.

31 As a sidenote, the Community Law in Deut 23:1-8 envisions the transition of certain exogenous others (Edomites and Egyptians) into the community of Israel. 
native Canaanites), the text of Deut 20:16-18 stipulates a categorical treatment: they must be annihilated altogether, keeping no men and women alive. In fact, further stipulations give clear indications that the indigenous Canaanites are to be destroyed, generally by expulsion or total annihilation and extermination (Exod 23:20-33; Deut 7).

To conclude, these indirect texts represent a twofold treatment of the exogenous and the indigenous others. In case of the former category of strangers, the legal treatment envisions forced labour for the men and cultural homogenization for the women, thus, the possibility of the transition of the exogenous others into the Israelite community is presupposed. In case of the latter category of strangers, the legal treatment envisions total annihilation, thus, the possibility of the transition of the indigenous others into the Israelite community is excluded. ${ }^{32}$

The law codes of the Pentateuch extensively refer to the מגוּרי , but the earliest legal references concerning the treatment of the in the OT are found in the Covenant Code (CC) and in the Deuteronomic Code (DC). ${ }^{33}$

\begin{tabular}{|l|c|l|}
\hline \multicolumn{3}{|c|}{ The occurrences of the term 7 in the early law codes of the Pentateuch } \\
\hline Law Codes & $\begin{array}{c}\text { Number of } \\
\text { appearances }\end{array}$ & Bible verses \\
\hline $\begin{array}{l}\text { Covenant Code } \\
\text { (Exod 20:22-23,33) }\end{array}$ & 6 & Exod 22:20(2x);23:9(3x), 12 \\
\hline $\begin{array}{l}\text { Deuteronomic Code } \\
\text { (Deut 12-26) }\end{array}$ & 13 & $\begin{array}{l}\text { Deut 14:21, 29;16:11, 14;23:8; } \\
24: 14,17,19,20,21 ; 26: 11,12, \\
13\end{array}$ \\
\hline
\end{tabular}

It must be emphasized that these early Pentateuchal laws which regulate the treatment of גוּרים within the Israelite community are absolutely unique in the ANE world. ${ }^{34}$ To this date, there have been no parallel ANE cultures which

32 For further analysis of the treatment of the Canaanites, see Arie Versluis, The Command to Exterminate the Canaanites: Deuteronomy 7 (OTS 71; Leiden: Brill, 2017).

33 Current critical scholarship dates the CC to the $8^{\text {th }}$ century and the DC to the $7^{\text {th }}$ century. Cf. Eckart Otto, "The Study of Law and Ethics in the Hebrew Bible / Old Testament," in Hebrew Bible / Old Testament. The History of Its Interpretation III/2 (ed. Magne Saebo; Göttingen: Vandenhoeck \& Ruprecht, 2015), 603-604.

34 "[...] ein spezifisch israelitisches Anliegen." Thomas M. Krapf, "Traditionsgeschichtliches zum deuteronomischen Fremdling-Waise-Witwe-Gebot," VT 34/1 (1984): 88. 
would protect the status of these so-called מֵּר by such laws, ${ }^{35}$ even though the legal protection of the widow, the orphan, and the poor (i.e. the personae miserae) is not unknown in the ANE world. ${ }^{36}$ However, the attachment of the גֶּרים invention. It is likely that the innovation of the protection of the הִרים in the OT laws is due to the deeply rooted experience of the Israelites themselves being

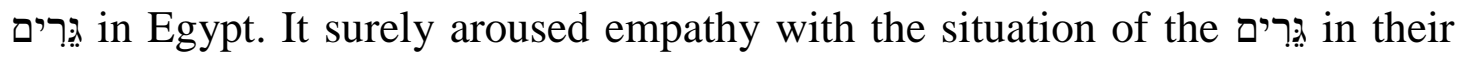
midst which is reflected in the motivational clauses of these early laws (cf. Exod 22:20; 23:9; Deut 16:12; 24:18, 22). ${ }^{37}$

Throughout a social-scientific reading, it is able to determine these specific laws' vision concerning the treatment and status of the within the Israelite community. First, it is evident, that the primary addressees of these laws were the local Israelites - more closely, the male heads of the Israelite households (due to their position of power within a patriarchal system). Therefore, these laws instructed and influenced the local Israelites concerning the rightful way of treating the גֵּרים. The laws do not contain sanctions. Thus, the

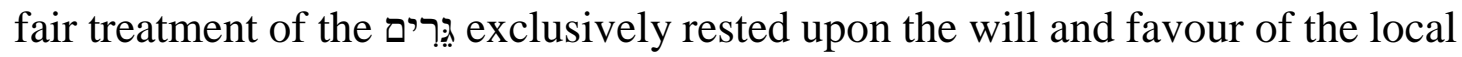

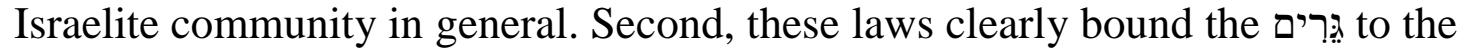
local Israelites by way of a dependent relationship in which the גִרים obtained preliminary rights. Their subordinate and dependent position is clear from the fact, that they could not own land in Israel.38 In sum, the status of the represented by these laws is an "in between" status - they are dependent, they do not own land, they are not fully integrated, and they are in a peripheral position within the local Israelite society. However, the laws clearly position them as free

35 Cf. Van Houten, The Alien in Israelite Law, 34. It must be noted that Ramírez Kidd, (Alterity and Identity, 111) adds that the ANE law codes do mention refugees (ecological, economic, and political) and runaway slaves. They could be regarded as sub-types of גְרִים

36 We have comparative material as early as from ancient Sumer. The protection of the widow, the orphan, and the poor is detailed in two well-known law codes, that of Urukagina of Lagash in the $25^{\text {th }}$ century B.C. and that of Ur Nammu, the founder of the so-called Third Dynasty of Ur in the $21^{\text {st }}$ century B.C. The most well-known of the law codes of Mesopotamia, the law of Hammurabi in the $18^{\text {th }}$ century B.C. builds upon the concepts of its Sumerian precursors. Cf. F. Charles Fensham, "Widow, Orphan, and the Poor in Ancient Near Eastern Legal and Wisdom Literature," JNES 21 (1962): 129139; Richard D. Patterson, "The Widow, the Orphan, and the Poor in the Old Testament and the Extra-Biblical Literature," BibSac 130 (1973): 223-234; Donald E. Gowan, "Wealth and Poverty in the Old Testament: The Case of the Widow, the Orphan, and the Stranger," Int 41 (1987): 341-353.

${ }^{37}$ For a critical analysis of the solidarity element, see Mark Sneed, "Israelite Concern for the Alien, Orphan, and Widow: Altruism or Ideology?" ZAW 111/4 (1999): 498507.

38 Nadav Na'aman, "Sojourners and Levites in the Kingdom of Judah in the Seventh Century BCE," ZAR 14 (2008), 240. 
members of the society, even if they do not obtain full rights. Therefore, they are clearly differentiated from the underclass of slaves and servants!

To conclude, the legal traditions of the OT are rather static and categorical regarding the differentiation of strangers; they minimize and give permission to utilize the relationship with the נְכְרים , but provide protection and ensure provisions for the גרים. In addition, the law codes are almost exclusively silent about the possibility of a certain stranger's transition from one category to the other. The indirect references in the Code of War in Deut 20 and its supplement in Deut 21:10-14 envision the possibility of transition of the exogenous others into the Israelite community, however, in case of the indigenous others (i.e. the native Canaanites); this possibility is categorically excluded.

\section{THE NARRATIVE REPRESENTATION OF STRANGER INCLUSION IN JOSHUA-JUDGES}

Following the brief orientation of the early laws, the present study attempts to analyse the Deuteronomic narrative traditions preserved in Joshua-Judges. Throughout these texts, it is somewhat possible to reach behind the figurative laws and imagine the everyday setting of the treatment and inclusion of strangers in ancient Israel.

\section{Rahab's household}

The first example concerning the treatment and inclusion of strangers in the narrative corpus of Joshua-Judges is the case of Rahab's household. ${ }^{39}$ The Rahab stories in Josh 2 and 6 are interwoven within the narratives of the siege of Jericho. In spite of God's commanded חרי on the Canaanites, the lives of Rahab's household (i.e. a Canaanite enclave of Jericho) are spared. ${ }^{40}$ In the following, an attempt is made to define the nature of Rahab's otherness, as well as the type of her inclusion within Israel.

39 Historical critical scholarship reckons the Rahab traditions to be independent, prior exiting traditions, which were part of the pre-Deuteronomistic conquest account. Cf. Anthony F. Campbell \& Mark A. O'Brien, Unfolding the Deuteronomistic History: Origins, Upgrades, Present Text (Minneapolis: Fortress Press, 2000), 109-112, 123. They were edited and embedded into the final form of the Book of Joshua by the Deuteronomistic authors. Cf. Bernard P. Robinson, "Rahab of Canaan-and Israel," SJOT 23/2 (2009): 259-261.

40 Cf. Victor Matthews, "Herem versus Hospitality in the Story of Rahab," in The Genre of Biblical Commentary: Essays in Honor of John E. Hartley on the Occasion of His $75^{\text {th }}$ Birthday (ed. Timothy D. Finlay \& William Yarchin; Eugene: Wipf \& Stock, 2015), 217. 
The first important information concerning Rahab's identity is found in

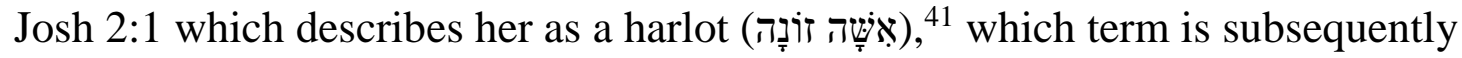
applied to her in Josh 6:17, 22, 25. According to Bird, in Israelite society, a harlot was "a marginal figure [...] tolerated but despised." 42 In fact, Prov 23:27 makes a definite connection between the harlot and the strange woman: "For a whore

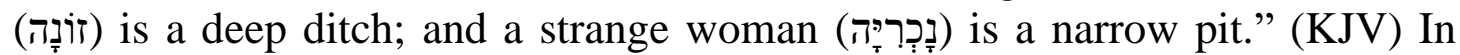
addition, the verbal root, זנה is a key verb to denote the passion and lust of the Israelites after the strange gods and strange practices of the other nations (cf. Exod 34:15-16; Deut 31:16; Judg 2:17; 8:27, 33). Thus, the characterization of Rahab as a harlot of Jericho makes her the least worthy to be saved for the Israelites. In other words, the status of Rahab as an indigenous other (i.e. Canaanite) and a harlot represents an ultimate and quintessential threat to the Israelite self-identity.

However, Rahab's quality is revealed in a completely different way throughout her deeds. First, in Josh 2:2-7 Rahab leads astray the chiefs of Jericho and saves the lives of the spies by hiding them in her house. Second, in Josh 2:811 she openly proclaims the mighty deeds of the LORD, moreover, she even testifies to her faith in Him by saying: "The LORD your God is indeed God in heaven above and on earth below." (Josh 2:11 NRSV) ${ }^{43}$ Thus, surprisingly the text represents Rahab as a true convert to Yahwism. "If Rahab is to be thought of as a convert to Yahwism, the ban can scarcely be taken to apply to her.",44

Following her testimony, Josh 2:12-21 is a detailed description of a treaty made between Rahab and the spies, ${ }^{45}$ which could be understood as an act of safeguarding a future patron-client relationship. In addition, they mutually swear an oath by the name of the LORD.

41 On the basis of the Septuagint, Josephus, and other Rabbinic sources, Riegner argues against the sexual connotations of האָשָׁ נָהזוֹ and favours the translation, "innkeeper". Irene E. Riegner, The Vanishing Hebrew Harlot: The Adventures of the Hebrew Stem ZNH (Studies in Biblical Literature 73; Bern: Peter Lang, 2009), 197199. On the contrary, Robinson still demonstrates the various sexual connotations hidden in Josh 2, thus, he favours the translation, "harlot". "No doubt the dividing line between the two businesses was blurred at times, so the word for female innkeeper could be used euphemistically for "harlot'." Robinson, "Rahab of Canaan," 264-265.

42 Cited by Robinson, "Rahab of Canaan," 265.

43 It is important to note, that Rahab's proclamation of the mighty deeds of the LORD in Josh 2:10-11a is regarded as later Deuteronomistic redaction from the time of Joshua, and Rahab's confession of faith in Josh 6:11b is regarded as post-Deuteronomistic addition. Cf. Campbell \& O'Brien, Unfolding the Deuteronomistic History, 111.

44 Robinson, "Rahab of Canaan," 269.

45 According to Robinson, "the sworn oath amounts to a covenant — and the language (ידע, ,אמת, חסד) is certainly suggestive of this." Robinson, "Rahab of Canaan," 269. For further details, see Ken M. Campbell, "Rahab's Covenant. A Short Note on Joshua 2:921," VT 22/2 (1972): 243-244. 


\section{Jenei, "Strategies for Stranger Inclusion," OTE 32/1 (2019): 127-154}

In Josh 6:22-25 it is briefly narrated how the Israelites treated Rahab's household after the siege. According to vv. 22-23, they are brought out of Jericho, and placed outside the camp of Israel. This liminal position could be understood as a temporal asylum-status. Then a little further, the text states that she dwelled in Israel and lived among the Israelites (v. 25). Instead of the standard verb (גור), the text uses ישב to describe Rahab's dwelling in Israel. However, ישב is a supporting and substituting verb in the OT narratives to denote the phenomena of sojourning and being a resident in the midst of another community. ${ }^{46}$

There are no further texts in the OT regarding Rahab, thus, a decision must be made on the ground of these texts (as well as later extra-biblical traditions) whether Rahab and her household were considered as גָּרִ in Israel.

First, the biblical texts overall depict Rahab and her household as The stages of their becoming anּרים are clear: 1) Rahab testifies to her faith in the LORD, swears an oath, shows loyalty, and intends to enter into a patron-client relationship; 2) then the fleeing refugees are seen in a temporary asylum status; 3) finally, they are seen as dwelling in the midst of Israel permanently. The etiological character of Josh 6:25 even strengthens this view, because it assumes that in a much later time, during the time of the later Deuteronomic redaction, they still live among Israel. ${ }^{47}$ Thus, the etiological statement of the text would not be necessary, if they would not become permanent residents in Israel.

Second, it is remarkable to see the extra-biblical progression of the Rahab tradition. Although there is no other reference to Rahab in the OT, neither outside the Book of Joshua, nor in the intertestamental Jewish literature and the Qumran sources, but the later rabbinic sources, as well as the NT and the early Christian fathers exalt the tradition and richly refer to Rahab's valour. For instance, the rabbinic sources confirm Rahab's inclusion in Israel by overly speculating upon her Israelite husband. In these sources Rahab is regarded as the wife of none other than Joshua himself. ${ }^{48}$ In addition, the NT sources picture Rahab as a true convert (she is included in the family tree of Jesus himself in the Matthean genealogy), as well as a role model of faith in the Letter to the Hebrews (11:31). ${ }^{49}$

46 Cf. footnote 14 above.

47 Cf. John Day, "Rahab," Anchor Bible Dictionary 5 (1992): 610. Micha Roi, "To This Day: Aetiology, Rhetoric, or Literary Motif?” SJOT 27/2 (2013): 285-295.

48 Richard J. Bauckham, "Tamar's Ancestry and Rahab's Marriage: Two Problems in the Matthean Genealogy," NovT 37/4 (1995): 320-329. Andrzej Toczyski, The 'Geometrics' of the Rahab Story: A Multi-Dimensional Analysis of Joshua 2 (HB/OT Studies 664; New York: T \& T Clark, 2018), 67-91.

49 Anthony T. Hanson, "Rahab the Harlot in Early Christian Tradition," JSNT 1 (1978): 53-60. H. F. Stander, "The Greek Church Fathers and Rahab," Acta Patristica 
In sum, the case of Rahab and her household in Josh 2 and 6 represents an assimilative strategy of stranger inclusion in Israel applied to smaller numbers of fleeing, converting, and intermarrying strangers. Thus, these texts authentically represent ancient refugees, patron-client relationships, asylumstatus, and the stages of integration and assimilation. The type of relationship pictured in the texts is a close, dependent one, in which the strangers gradually lose their previous identity unto the point when they are fully integrated and assimilated into the hosting community. From the viewpoint of the Israelite local community, this type of sojourning mode was the preferred type, because it was rather easy to integrate a small number of willingly converting strangers; their presence within the Israelite society did not represent any threat. In fact, the cultural memory of the local community preserved the sojourning of Rahab and his household in Israel as the ideal example of immigration and the ultimate model of conversion. In addition, it is important to note that the narrative traditions of Rahab are dynamic representations of stranger inclusion, in which the transitional process is particularly captured. Spina's phrasing sums it up well: "outsiders are only a confession away from being included". 50

\section{Kenites}

Another type of local-stranger relationship is represented in Joshua-Judges by the status and treatment of the Kenites. ${ }^{51}$ The name of the Kenites is derived from the Semitic root, קין which refers to metal-working ${ }^{52}$ and singing. Semantically

et Byzantina 17 (2006): 37-49. Y. Zakowitch, "Rahab als Mutter des Boas in der JesusGenealogie (Matth. I 5)," NovT 17/1 (1975): 1-5.

50 Frank A. Spina, The Faith of the Outsider: Exclusion and Inclusion in the Biblical Story (Grand Rapids/Cambridge: Eerdmans, 2005), 71.

51 Landmark studies on the Kenites include: Charles F. Fensham, "Did a Treaty between the Israelites and the Kenites Exist?" BASOR 175 (1964): 51-54. Gary Nolan, The Role of the Kenites in Israel's History (ThD Diss.; New Orleans: Baptist Theological Seminary, 1982). Isaac Kalimi, "Three Assumptions about the Kenites," ZAW 100/3 (1988): 386-393. J. David Schloen, "Caravans, Kenites, and Casus Belli: Enmity and Alliance in the Song of Deborah," CBQ 55 (1993): 18-38. Paula M. McNutt, "The Kenites, the Midianites, and the Rechabites as marginal mediators in ancient Israelite tradition," Semeia 67 (1994): 109-132. Don C. Benjamin, "Response to Paula M. McNutt: The Kenites, the Midianites, and the Rechabites," Semeia 67 (1994), 133-146. Joseph Blenkinsopp, "The Midianite-Kenite Hypothesis Revisited and the Origins of Judah," JSOT 33/2 (2008): 131-153. Marlene E. Mondriaan, "Who were the Kenites?" OTE 24/2 (2011): 414-430. Nadav Na'aman, "The »Kenite Hypothesis « in the Light of the Excavations at Horvat 'Uza," in Not Only History: Proceedings of the Conference in Honor of Mario Liverani (ed. Gilda Bartoloni, Maria G. Biga \& Armando Bramanti; Winona Lake: Eisenbrauns, 2016), 171-182.

52 For detailed analyses of metalworking in OT times with reference to the Kenites, cf. Nissim Amzallag, "Copper Metallurgy: A Hidden Fundament of the Theology of Ancient Israel," SJOT 27/2 (2013): 151-169. Emanuel Pfoh, "Metalworkers in the Old Testament: An Anthropological View," in Methods, Theories, Imagination: Social 
the root closely relates to the name of the biblical figure, Cain. It is noteworthy that Gen 4 represents the descendants of Cain as cultural inventors; they are the ones who teach humanity about nomadism, metalworking, and musical culture. Therefore, the sojourning and wandering Cain could be understood as the common ancestor of the biblical Kenites, thus, most likely the biblical traditions concerning Cain and his descendants preserved in the Book of Genesis are integrated and edited versions of the origin myths of the Kenites. ${ }^{53}$

It is widely attested by Biblical and extra-biblical sources that the area of the Negev in the ancient times was inhabited by a number of proto-Arabic clans. These clans, the Ismaelites, the Midianites, the Kenites, the Calebites, the Amalekites, the Edomites, and the Kenizzites more or less acknowledged the supremacy and control of the Israelite clans above themselves. However, they followed and maintained their own lifestyle in the southern deserts, further away south from the territories of the central hill area where the proto-Israelites first appeared in Palestine during the early Iron Age. Therefore, these kindred clans of the Negev lived in a neighbouring position with the Israelites. The territory of their interests differed, therefore, the Israelites and the proto-Arabic clans of the Negev were not in a concurring position. At the same time, mutual relationships, treaties and intermarriages could easily occur between the southern tribes of Israel (Judah, Simeon) and the clans of the Negev. In fact, Judg 1:16 and 4:11 clearly states that the Kenites were Moses's relatives; therefore, the Kenites are represented as closely related to the Midianites as well. They were the southern neighbours of the tribe of Judah; they lived in tents and maintained their nomadic lifestyle. $^{54}$

What type of relationship did exist between the Israelites and the Kenites during the settlement period? Although the biblical account attests loose kindred

Scientific Approaches in Biblical Studies (ed. D. J. Chalcraft, F. Uhlenbruch \& R. S. Watson; The Bible and Social Science 1; Sheffield: Sheffield Phoenix Press, 2014), 201-217.

53 Cf. H. Zeydner, "Kainszeichen, Keniter und Beschneidung," ZAW 18/1 (1898): 120-125. J. Maxwell Miller, "The Descendants of Cain: Notes on Genesis 4," ZAW 86 (1974): 164-174. John Day, "Cain and the Kenites," in Homeland and Exile: Biblical and Ancient Near Eastern Studies in Honour of Bustenay Oded (ed. Gershon Galil, Markham J. Geller \& Alan Millard; VTSup 130; Leiden: Brill, 2009), 335-346.

54 It is rather interesting to note that according to $2 \mathrm{Kgs} 10$, Jer 35, and 1Chron 2:55 the later descendants of the Kenites, that of the Rechabites still maintained their nomadic lifestyle and represented the nomadic ideal in Israel. Cf. Frank S. Frick, "The Rechabites Reconsidered," JBL 90 (1971): 279-287., Chris H. Knights, "Kenites=Rechabites? 1 Chronicles ii 55 Reconsidered," VT 43/1 (1993): 10-18. Karel van der Toorn, "Ritual Resistance and Self-assertion: The Rechabites in Early Israelite Religion," in Pluralism and Identity: Studies in Ritual Behaviour (ed. Jan Platvoet \& Karel van der Toorn; Studies in the History of Religions 67. Leiden: Brill, 1995), 229259. 
relations between the Israelites and the Kenites, it is also unquestionably presented that the Kenites had a distinguishable identity and lifestyle, which they maintained in the neighbourhood and the peripheries of the early Israelite settlements. Their nomadic lifestyle and their unique profession, metalworking (which is supposed based on their name and origins myths) set them apart from the early Israelites. Thus, their relationship with the Israelites was not a subordinate, patron-client type relationship, but a coordinate, neighbouring relationship, which was sealed by distant kinships and occasional treaties and loyalty oaths. This type of peaceful, covenantal relationship between the Israelites and the Kenites is represented at large by the account of Judg $4 .^{55}$ According to the text, the house of Heber left the southern Kenites and wandered up to the northern regions. They are still pictured as nomadic tribes living in the neighbourhood of the local Canaanite city-states and the peripheries of the protoIsraelite settlements. Although they maintained peaceful relationships with both the Canaanite city-state, Hazor and the people of Israel, ${ }^{56}$ the conflict between the king of Hazor and the northern Israelite tribes forced them to commit their loyalty exclusively either to Hazor or Israel. The liminal nature of their political stand is effectively decided by a hand of a woman and a tent peg. ${ }^{57}$

On the basis of the biblical accounts, the Kenites were independent of the Israelites, thus, they were not regarded as in Israel. However, the Kenites' independent status could easily turn to a closer, more dependent status due to occasional military, economic and ecological crises, or throughout exogamic marriages; thus, certain Kenite individuals or families could easily become in Israel. Therefore, peaceful, neighbouring relationships naturally contain the possibility of closer, dependent relationships; hence the peaceful, neighbouring relationship is the forerunner of permanent residency and assimilation. In fact, it is noteworthy to briefly refer to the status of the Calebites, who were kindred clans of the Kenites, originating from the Negev area. ${ }^{58}$ In case of the Calebites,

55 The account is regarded as part of the pre-Deuteronomistic deliverance collection, cf. Campbell and O'Brien, Unfolding the Deuteronomistic History, 179-180.

56 Their peaceful relationship with the city of Hazor is described by the term, שָלוֹם (Judg 4:17).

57 Matthews and Benjamin draw attention to the cultural background of the text which clearly helps to understand Jael's decision. According to the ancient protocol of the custom of hospitality, approaching the woman's tent - instead of approaching the male household's tent - is a serious breach of custom, thus, Sisera's aggressive appearance and his breach of custom overruled the sacred law of hospitality and the peace treaty between Hazor and the Kenites. Cf. Matthews \& Benjamin, Social World of ancient Israel, 87-94. In addition, it is important to note that the reference to Jael's heroic deed in the Song of Deborah (Judg 5:24-27) is rather revealing about the early origin of this tradition.

58 Concerning the Calebites, see Walter Beltz, Die Kaleb-Tradition im Alten Testament (Stuttgart: Kohlhammer, 1974). James H. Pace, The Caleb traditions and the role of the Calebites in the history of Israel (PhD Diss., Emory University, 1976). 


\section{Jenei, "Strategies for Stranger Inclusion," OTE 32/1 (2019): 127-154}

the biblical accounts keep the tradition that they nurtured a closer, dependent relationship with the Israelites. During the Israelite conquest, Caleb played an important role, whereupon he and his descendants inherited the city of Hebron (cf. Josh 15:13-19), which was one of the cities of refuge and asylum. Thus, the conquest accounts indirectly show that the Calebites became real גֶים, sojourners in the midst of Israel, what is more, the Israelites successfully assimilated them throughout time (cf. Josh 15:13-19; Judg 1:13-15; 1Chron 2:42-49). There is only one negative account concerning the integration of the Calebites: the story of Nabal in 1 Sam 25. This chapter tells the story of a wealthy landlord and livestock owner, Nabal, who, contrary to his Calebite lineage and welcomed status, shows disrespect and inhospitality toward the wandering and sojourning David and his men. ${ }^{59}$

In sum, the nature of the relationship between the Israelites and the Kenites is best described as peaceful neighbourhood, thus, the case of the Kenites in Judges 4-5 and beyond represents a neighbouring strategy of peaceful relationship applied to special clans of strangers who possessed a unique lifestyle or profession. The peaceful relationship is maintained on the basis of loose kindred relations (cf. Judg 1:16; 4:11), differing territorial interests, and possible economic and commercial contacts. The borders and peace between these neighbouring communities were fixed and agreed (cf. Gen 21:22-32; 26:12-31; 31:43-32:1). At the same time, crises or exogamic marriages could turn neighbouring relationships into closer, dependent patron-client relationships, and in a long run, permanent residency and assimilation. On the other hand, the clash of interests could turn this type of relationship into hostility. ${ }^{60}$

\section{The Gibeonites}

Finally, a harsher type of local-stranger relationship is represented in JoshuaJudges by the status and treatment of the Gibeonites. ${ }^{61}$ The first reference to the

Joseph Fleishman, "A daughter's demand and a father's compliance: The legal background to Achsah's claim and Caleb's agreement (Joshua 15, 16-19; Judges 1,1215)," ZAW 118/3 (2006): 354-373. Jacob L. Wright, David, King of Israel, and Caleb in Biblical Memory (Cambridge: Cambridge University Press, 2014).

59 For further study, see Joseph Lozovyy, Saul, Doeg, Nabal, and the "Son of Jesse". Readings in 1 Samuel 16-25 (HB/OT Studies 497; New York: T \& T Clark, 2011), 5183.

60 For further study of the OT models of inclusion and the representations of clash and coexistence between the Israelites and the strangers, see Elöd Hodossy-Takács "Clash and Coexistence in Ancient Palestine," in Ein pralles Leben: Alttestamentliche Studien. Für Jutta Hausmann zum 65. Geburtstag und zur Emeritierung (ed. Éva P. Verebics, Nikolett Móricz \& Miklós Köszeghy; Arbeiten zur Bibel und ihrer Geschichte 56. Leipzig: Evangelische Verlangsanstalt, 2017), 343-352.

61 Landmark studies on the biblical Gibeonites include: Menahem Haran, "The Gibeonites, the Nethinim and the Sons of Solomon's Servants," VT 11/1 (1961): 159- 
Gibeonites in the biblical account is found in Josh $9 .{ }^{62}$ From the point of view of the Israelites and the later redaction, this narrative is an etiological type of narrative which functions as an explanation of how and why the Gibeonites even though they originally belonged to the Canaanite population - escaped the חָר.

According to the biblical account, the Gibeonites ethnically belonged to the Hivite population of Canaan (cf. Josh 9:7; 9:19). ${ }^{63}$ The biblical accounts report a wide range of Canaanite localities which were inhabited by the Hivites: Shechem, Mizpah, Lebanon, Tyre, Sidon (Gen 34:2; Josh 11:3; Judg 3:3; 2Sam

169. Joseph Blenkinsopp, Gibeon and Israel: The Role of Gibeon and the Gibeonites in the Political and Religious History of Early Israel (SOTSMS 2; Cambridge: Cambridge University Press, 1972). J. Halbe, "Gibeon und Israel: Art, Veranlassung und Ort der Deutung ihres Verhältnisses in Jos. IX," VT 25 (1975): 613-641. Jacques Briend, "Israël et les Gabaonites," in La Protohistoire d'Israël: De l'exode à la monarchie (ed. E.-M. Laperrousaz; Paris: Cerf, 1990), 121-182. Ray K. Sutherland, "Israelite Political Theories in Joshua 9," JSOT 53 (1992): 65-74. Diana Edelman, "Gibeon and the Gibeonites Revisited," in Judah and the Judeans in the NeoBabylonian Period (ed. O. Lipschitz \& J. Blenkinsopp; Winona Lake: Eisenbrauns, 2003), 153-167. Robert P. Gordon, "Gibeonite Ruse and Israelite Curse in Joshua 9," in Covenant in Context: Essays in Honour of E. W. Nicholson (ed. A. D. H. Mayes \& R. B. Salters; Oxford: Oxford University Press, 2003), 163-190. John Day. "Gibeon and the Gibeonites in the Old Testament," in Reflection and Refraction: Studies in Biblical Historiography in Honour of A. Graeme Auld (ed. R. Rezetko, T. H. Lim \& A. B. Aucker; VTSup 113; Leiden/Boston: Brill, 2007), 113-137. Jacob L. Wright, "Rahab's Valor and the Gibeonites' Cowardice," in Worship, Women and War: Essays in Honor of Susan Niditch (ed. John J. Collins, T. M. Lemos \& Saul M. Olyan; Brown Judaic Studies 357; Atlanta: SBL Press, 2015), 199-211. William A. Ford, "What about the Gibeonites?" Tyndale Bulletin 66/2 (2015): 197-216.

62 Landmark studies concerning literary and redactional issues in Josh 9 include: Jacob Liver, "The Literary History of Joshua IX," JSS 8 (1963): 227-243. Joseph Blenkinsopp, "Are There Traces of the Gibeonite Covenant in Deuteronomy?" $C B Q 28$ (1966): 207-213. Peter J. Kearney, "The Role of the Gibeonites in the Deuteronomic History," CBQ 35 (1973): 1-19. Andrew D. H. Mayes, "Deuteronomy 29, Joshua 9, and the Place of the Gibeonites in Israel," in Das Deuteronomium: Entstehung, Gestalt und Botschaft (ed. Norbert Lohfink; BETL 68; Leuven: Peeters, 1985), 321-325. Christa Schäfer-Lichtenberger, "Das gibeonitische Bündnis im Lichte deuteronomischer Kriegsgebote: Zum Verhältnis von Tradition und Interpretation in Jos 9," BN 34 (1986): 58-81. K. Latvus, "From Army Campsite to Partners in Peace: The Changing Role of the Gibeonites in the Redaction Process of Josh. x 1-8; xi 19," in "Lasset uns Brücken bauen..." Collected Communications to the XVIth Congress of the International Organization for the Study of the Old Testament, Cambridge 1995 (ed. K.-D. Schunck \& M. Augustin; BEATAJ 42; Frankfurt aM.: Peter Lang, 1998), 111-115. Christoph Berner, "The Gibeonite Deception: Reflections on the Interplay between Law and Narrative in Josh 9," SJOT 31/2 (2017): 254-274.

63 Cf. Haran, "The Gibeonites," 159. 
24:6-7). ${ }^{64}$ According to Josh 9, the Gibeonites lived in the settlements of Gibeon, Chephirah, Beeroth and Kiryath-Yearim (Josh 9:17). ${ }^{65}$ When the biblical localities connected to the Hivites are pictured, it becomes clear that their settlements did not construct a uniform pattern; in addition, the Gibeonites could be understood as the southernmost enclave of the remnant population of the Hivites. ${ }^{66}$

In the following, it is examined how the biblical texts describe the relationship between the Israelites and the Gibeonites. According to Josh 9:6 the main intention of the Gibeonites is to force a protected status from the conquering Israelites. Their trick is to present themselves as sojourning asylumseekers from a distant land in order to press out a treaty (Joh 9:4-6, 12-13). According to the rhetoric of the biblical text, the success of their plan rested upon an ancient convention of asylum-right, which obliged to the Israelites - as the dominant group - to show compassion and provide asylum for the refuging group by way of a covenantal relationship. It is important to understand the nature of this treaty or covenant. ${ }^{67}$ According to the text, the Gibeonites counted on a patron-client type relationship in order to secure their survival. The patron-client rhetoric is present in the text itself; the Gibeonites refer to themselves as the servants of Joshua (Josh 9:8), then they apply this servant-rhetoric throughout the whole process of negotiation (Josh 9:23, 24).

In the following, the text represents that the Israelites are eager and excited to enter into this relationship as patrons, i.e. as the dominant party. The text suggests that a subordinate patron-client relationship sealed by covenant was as much wished by the dominant party as it was by the subordinate party. Throughout this type of relationship, the patrons gained loyal servants, while the clients gained survival, protection, and material resources. Such subordinate relationships were widespread in the ANE and they were beneficial for both parties. ${ }^{68}$ Thus, Josh 9 nurtures the tradition that throughout the treaty the Gibeonites became protected residents within Israel, although in a subordinate position.

\footnotetext{
64 Cf. Haran, "The Gibeonites," 159-160.

65 Cf. Haran, "The Gibeonites," 160.

66 Cf. Haran, "The Gibeonites," 160.

67 Cf. Charles F. Fensham "The Treaty between Israel and the Gibeonites," BA 27/3

(1964): 96-100. Hartmut N. Rösel, “Anmerkungen zur Erzählung vom Bundesschluss mit den Gibeoniten," BN 28 (1985): 30-35.

68 Cf. Niels P. Lemche, "From Patronage Society to Patronage Society," in The Origins of the Ancient Israelite States (ed. Volkmar Fritz \& Philip R. Davies; JSOTSup 228; Sheffield: Sheffield Academic Press, 1996), 106-120. Raymond Westbrook, "Patronage in the ancient Near East," JESHO 48/2 (2005): 210-233. Emanuel Pfoh, "Some Remarks on Patronage in Syria-Palestine during the Late Bronze Age," JESHO 52/3 (2009): 363-381.
} 
Moving forward, it is also important to investigate how this patron-client relationship became an oppressive and exploiting type of relationship for the Gibeonites. After the Israelites found out the ruse, they felt it legitimate to degrade the Gibeonites' client-status to a lower servant-status (Josh 9:20-21). Their servant-status materialized in corvée/forced labour around the altar of the LORD, ${ }^{69}$ more precisely, they became "hewers of wood and drawers of water" (Josh 9:27). "Needless to say, the office in question [...] was of the most menial kind, hardly distinguishable from slavery."70 Following the Deuteronomic history, the Gibeonites remained in the area of Gibeon as an ethnic minority, making a living as forced labourers. ${ }^{71}$

When the Deuteronomic laws are considered concerning the status and treatment of the non-assimilated indigenous strangers (i.e. the Canaanites) and the semi-assimilated, protected strangers, it is clear that the legal statuses depicted in the laws are in tension with the status of the Gibeonites pictured in the Book of Joshua. In other words, if the Gibeonites were reckoned as nonassimilated strangers (i.e. זָכְָרִי is too gracious, however, if they were reckoned as semi-assimilated, protected

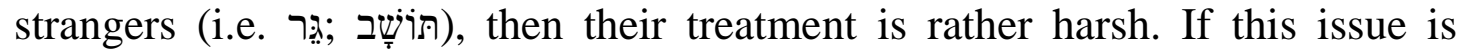
approached with a historical-critical angle, then it is possible to understand the function of the etiological narrative of Josh 9: a Deuteronomic attempt to interpret and legitimize the peculiar treatment toward the Gibeonites. ${ }^{72}$

69 The altar of the LORD supposedly means Gibeon, thus, the native Gibeonites became the servants of the local cult. Cf. Mark Leuchter, "The Cult of Kiriath Yearim: Implications from the Biblical Record," VT 58 (2008): 526-543. Nadav Na'aman, "The Sanctuary of the Gibeonites Revisited," JANER 9 (2009): 101-124.

70 Haran, "The Gibeonites," 161.

71 According to Menahem Haran, the Gibeonites supposedly preserved their distinct identity until the time of the early Israelite monarchy under Saul, David and Solomon. After this time, there is no more mention of the Gibeonites. Cf. Haran, "The Gibeonites," 161.

72 Recently Christoph Berner provided an in-depth analysis of Josh 9 concerning its complex redaction history. This brief outline is based on his own words provided in the abstract. His analysis shows that the earliest version of the text provided an impartial portrayal of the peace treaty between Gibeon and Israel. After the emergence of the law of (Deut 20:15-18), this original version of Josh 9 implied an open contradiction against Deuteronomy's warfare legislation. As a result, a first Deuteronomic editor (D1) introduced the idea that the Gibeonites had tricked the Israelites into making a covenant and thus saved their lives with deceit. At this stage of the literary development, the prohibition of making a covenant with the inhabitants of the land (e.g. Deut 7:2) was not in view yet. Compared to the חרים the respective prohibition represents a later stage in the development of the legal material (perhaps triggered by the D1 version of Josh 9). This later development of the Deuteronomic legal material is only reflected in a second Deuteronomistic layer (D2) of the chapter, which finally received one more 
In sum, in a sociological sense the case of the Gibeonites represents the phenomenon of mass-migration, which raised fear within the local community. Therefore, instead of the strategy of integration and assimilation - which works well with smaller groups - the Israelites applied the strategy of subordination and oppression. This oppression could take the forms of temporary corvée labour, perpetual slavery, or - in a worst case scenario - even extermination. ${ }^{73}$

\section{E CONCLUSION}

A synchronic analysis of the early legal material (Covenant Code, Deuteronomic Code) and the narratives in Joshua-Judges concerning the status and treatment of strangers reveals that the legal material is in conflict with the narrative representation on several occasions. 1) Although the law codes in question are aware of the difference between the non-assimilated stranger (ינָכִר ) and that of the semi-assimilated stranger ( $า$ ), they are almost exclusively silent about the possibility of a certain stranger's transition from one category to the other. Only indirect references in the Code of War in Deut 20; 21:10-14 and the Community Law in Deut 23:1-8 envision the possibility of transition of certain exogenous others - the non-Canaanites - into the Israelite community. On the other hand, the narratives in Joshua-Judges are especially rich in representations of stranger inclusion within the Israelite community; in addition, they picture customary mechanisms concerning the process of transition. 2) Concerning the status and treatment of the non-assimilated Canaanite population, the legal material is rather harsh and categorical: the possibility of the inclusion of the indigenous others (i.e. the native Canaanites) is categorically excluded. On the contrary, the cases of Rahab's household and the Gibeonites in the Book of Joshua clearly witness that certain Canaanite enclaves found their way into the community of Israel. 3) Concerning the status and treatment of the semi-assimilated strangers, the גָרִ the legal material is rather humanitarian and idealistic: they provide protection and ensure extensive provisions for them; in addition, the laws clearly position them as free members of the society. On the other hand, the case of the semi-assimilated Gibeonites in the Book of Joshua and beyond represents the vulnerability of their protected status, which was liable to oppression and violence. Their forced-labourer status in Josh 9 is a lowered and degraded status

major editorial reworking by a priestly hand. Cf. Berner, "The Gibeonite Deception," 254-274, especially the Appendix in 272-274.

73 On the basis of 2Sam 21:2-6, it is possible to reconstruct the later destiny of the Gibeonites preserved in Israelite cultural memory. This narrative is about David's provision of justice to the Gibeonites for the deeds of Saul, who most likely executed an ethnic genocide around Gibeon. Cf. Henri Cazelles, "David's Monarchy and the Gibeonite Claim (II Sam. xxi, 1-14)," PEQ 87 (1955): 165-175. Joseph Blenkinsopp, "Did Saul Make Gibeon His Capital?" VT 24 (1974): 1-7. John van Seters, "David and the Gibeonites." ZAW 123/4 (2011): 535-552. 
(type of slavery) compared to the protected status; what is more, King Saul's genocide within the Gibeonite community is utterly against the legal ideals.

A diachronic analysis of the same legal and narrative material provides helpful solutions concerning the above-mentioned conflicts. 1) The traditions concerning Rahab's inclusion, the Kenites' peaceful relationship with the early Israelites, the Calebites' close relationship with the Judahites, and the Israelite treaty with the Gibeonites show early, pre-Deuteronomic origin. 2) The Code of War in Deuteronomy (Deut 20) and its harsh idea of the (Deut 20:15-18), moreover, the overall Deuteronomic legal prohibition against the inclusion of the Canaanites (Deut 7:2) emerged at a later stage, as well as the legal protection of the 9 in the Covenant Code and the Deuteronomic Code $\left(8^{\text {th }}-7^{\text {th }}\right.$ centuries BCE and beyond). 3) The exilic and post-exilic Deuteronomic and Priestly redactions - particularly in the stories of Rahab (her proclamation of YHWH's mighty deeds and her confession in Josh 6:10-11) and the Gibeonites (the idea of their ruse and trickery) - provided elements which intended to ease and harmonize the narratives with the later legal traditions.

Finally, from the point of view of cultural anthropology and social history, the Books of Joshua and Judges represent three distinct types of stranger inclusion strategies, in which the transitional process of the strangers is captured dynamically, in a custom-like manner. 1) The strategy of assimilation was applied to smaller numbers of fleeing, converting, and intermarrying strangers. The case of Rahab's household shows a close, dependent relationship, in which the strangers gradually lose their previous identity unto the point when they are fully integrated and assimilated into the hosting community. From the viewpoint of the Israelite local community, this type of sojourning mode was the preferred type, because it was rather easy to integrate a small number of willingly converting strangers; their presence within the Israelite society did not represent any threat. 2) The strategy of maintaining peaceful neighbouring relations was applied to special clans of strangers who possessed a unique lifestyle or profession. The case of the Kenites shows that the peaceful relationship was maintained on the basis of loose kindred relations, differing territorial interests, and possible economic and commercial contacts. The borders and peace between these neighbouring communities were fixed and agreed; however, crises or exogamic marriages could turn neighbouring relationships into closer, dependent patron-client relationships, and in a long run, permanent residency and assimilation. On the other hand, the clash of interests could turn this type of relationship into hostility. 3) The strategy of subordination and oppression was applied to larger numbers of mass-migrants. The case of the Gibeonites represents the phenomenon of mass-migration, which raised fear within the local community. Therefore, instead of the strategy of integration and assimilation which worked well with smaller groups -, the Israelites applied the strategy of subordination and oppression. This oppression could take the forms of temporal corvée labour, perpetual slavery, or - in a worst-case scenario - even 
extermination. If these stranger inclusion strategies in Joshua-Judges are not mere literary devices but culturally adequate reflections of ancient Near Eastern and ancient Israelite social customs, then it could mean that the laws concerning the treatment of non-assimilated strangers and semi-assimilated sojourners arrived to a context where a rather rigorous customary treatment toward strangers already existed.

\section{BIBLIOGRAPHY}

Achenbach, Reinhard, Rainer Albertz \& Jakob Wöhrle, eds. The Foreigner and the Law: Perspectives from the Hebrew Bible and the Ancient Near East. BZAR 16. Wiesbaden: Harrassowitz Verlag, 2011.

Amzallag, Nissim. "Copper Metallurgy: A Hidden Fundament of the Theology of Ancient Israel." SJOT 27/2 (2013): 151-169. https://doi.org/10.1080/09018 328.2013.839105.

Awabdy, Mark A. Immigrants and Innovative Law: Deuteronomy's Theological and Social Vision for the גר . FAT 67. Tübingen: Mohr Siebeck, 2014.

Bauckham, Richard J. "Tamar's Ancestry and Rahab's Marriage: Two Problems in the Matthean Genealogy." NovT 37/4 (1995): 313-329. https://doi.org/10.1163/156 $\underline{8536952663168 .}$.

Beltz, Walter. Die Kaleb-Tradition im Alten Testament. Stuttgart: Kohlhammer, 1974. Benjamin, Don C. "Response to Paula M. McNutt: The Kenites, the Midianites, and the Rechabites." Semeia 67 (1994), 133-146.

Bennett, Harold V. Injustice Made Legal: Deuteronomic Law and the Plight of Widows, Strangers, and Orphans in Ancient Israel. The Bible in Its World. Grand Rapids/Cambridge: Eerdmans, 2002.

Berner, Christoph. "The Gibeonite Deception: Reflections on the Interplay between Law and Narrative in Josh 9," SJOT 31/2 (2017): 254-274. https://doi.org /10.1080/09018328.2017.1333766.

Bertholet, Alfred. Die Stellung der Israeliten und der Juden zu den Fremden. Basel/Freiburg/Leipzig: J. C. B. Mohr (Paul Siebeck), 1896.

Blenkinsopp, Joseph. "Are There Traces of the Gibeonite Covenant in Deuteronomy?" CBQ 28 (1966): 207-213. - Gibeon and Israel: The Role of Gibeon and the Gibeonites in the Political and Religious History of Early Israel. SOTSMS 2. Cambridge: Cambridge University Press, 1972.

—. "Did Saul Make Gibeon His Capital?" VT 24 (1974): 1-7. https://doi.org/ 10.1163/156853374X00530.

. "The Midianite-Kenite Hypothesis Revisited and the Origins of Judah." JSOT 33/2 (2008): 131-153. https://doi.org/10.1177/0309089208099253.

Bodi, Daniel. "Outraging the resident-alien: King David, Uriah the Hittite, and an ElAmarna parallel." UF 35 (2003): 29-56.

Briend, Jacques. "Israël et les Gabaonites." Pages 121-182 in La Protohistoire d'Israël: De l'exode à la monarchie. Edited by E.-M. Laperrousaz, Paris: Cerf, 1990.

Bultmann, Christoph. Der Fremde im antiken Juda: Eine Untersuchung zum sozialen Typenbegriff "gēr" und seinem Bedeutungswandel in der alttestamentlichen Gesetzgebung. FRLANT 153. Göttingen: Vandenhoeck \& Ruprecht, 1992. https://doi.org/10.13109/9783666538346. 
Campbell, Anthony F. \& Mark A. O'Brien. Unfolding the Deuteronomistic History: Origins, Upgrades, Present Text. Minneapolis: Fortress Press, 2000.

Campbell, Ken M. "Rahab's Covenant: A Short Note on Joshua 2:9-21." VT 22/2 (1972): 243-244. https://doi.org/10.2307/1517249.

Cazelles, Henri. "David's Monarchy and the Gibeonite Claim (II Sam. xxi, 1-14)" PEQ 87 (1955): 165-175.

Day, John. "Rahab." Pages 610-611 in vol. 5 of Anchor Bible Dictionary. Edited by David Noel Freedman. 6 vols. New York: Doubleday, 1992.

- "Gibeon and the Gibeonites in the Old Testament." Pages 113-137 in Reflection and Refraction: Studies in Biblical Historiography in Honour of A. Graeme Auld. Edited by R. Rezetko, T. H. Lim \& A. B. Aucker. VTSup 113. Leiden/Boston: Brill, 2007.

_ . "Cain and the Kenites." Pages 335-346 in Homeland and Exile: Biblical and Ancient Near Eastern Studies in Honour of Bustenay Oded. Edited by Gershon Galil, Markham J. Geller \& Alan Millard; VTSup 130; Leiden: Brill, 2009.

Ebach, Ruth. Das Fremde und das Eigene: Die Fremdendarstellungen des Deuteronomiums im Kontext israelitischer Identitätskonstruktionen. BZAW 471. Berlin/New York: Walter de Gruyter, 2014. https://doi.org/10.1515/9783 110362329.

Edelman, Diana. "Gibeon and the Gibeonites Revisited." Pages 153-167 in Judah and the Judeans in the Neo-Babylonian Period. Edited by O. Lipschitz \& J. Blenkinsopp. Winona Lake: Eisenbrauns, 2003.

Fensham, F. Charles. "Widow, Orphan, and the Poor in Ancient Near Eastern Legal and Wisdom Literature" JNES 21 (1962): 129-139. https://doi.org/10.108 $\underline{6 / 371679}$.

. "Did a Treaty between the Israelites and the Kenites Exist?" BASOR 175 (1964): 51-54. https://doi.org/10.2307/1355826.

—. "The Treaty between Israel and the Gibeonites." BA 27/3 (1964): 96-100. https://doi.org/10.2307/3211010.

Fleishman, Joseph. "A daughter's demand and a father's compliance: The legal background to Achsah's claim and Caleb's agreement (Joshua 15,16-19; Judges 1,12-15)." ZAW 118/3 (2006): 354-373. https://doi.org/10.1515/ZAW.2006.019.

Ford, William A. "What about the Gibeonites?" Tyndale Bulletin 66/2 (2015), 197 216.

Frevel, Christian, ed. Mixed marriages: Intermarriage and group identity in the Second Temple Period. HB/OT Studies 547. New York: T \& T Clark, 2011.

Frick, Frank S. “The Rechabites Reconsidered.” JBL 90 (1971): 279-287. https://doi. org/10.2307/3262717.

Glanville, Mark R. Adopting the Stranger as Kindred in Deuteronomy. Ancient Israel and Its Literature 33. Atlanta: SBL Press, 2018. https://doi.org/10.2307/j.c tv6zddg1.

Gordon, Robert P. "Gibeonite Ruse and Israelite Curse in Joshua 9." Pages 163-190 in Covenant in Context: Essays in Honour of E. W. Nicholson. Edited by A. D. H. Mayes \& R. B. Salters. Oxford: Oxford University Press, 2003. https://doi.org /10.1093/acprof:oso/9780199250745.003.0009.

Gottwald, Norman K. The Tribes of Yahweh. A Sociology of the Religion of Liberated Israel, 1250-1050 B.C.E. Maryknoll, NY: Orbis, 1979. 
Gowan, Donald E. "Wealth and Poverty in the Old Testament: The Case of the Widow, the Orphan, and the Stranger." Int 41 (1987): 341-353. https://doi.org/10.1177/00 2096438704100402.

Guttmann, Michael. "The Term 'Foreigner' (נכרי) Historically Considered." HUCA 3 (1926): 1-20.

Haarmann, Volker. JHWH-Verehrer der Völker: Die Hinwendung von Nichtisraeliten zum Gott Israels in alttestamentlichen Überlieferungen. Zürich: Theologischer Verlag Zürich, 2008.

Halbe, J. "Gibeon und Israel: Art, Veranlassung und Ort der Deutung ihres Verhältnisses in Jos. IX.” VT 25 (1975): 613-641.

Hanson, Anthony T. "Rahab the Harlot in Early Christian Tradition." JSNT 1 (1978): 53-60. https://doi.org/10.1177/0142064X7800100106.

Haran, Menahem. "The Gibeonites, the Nethinim and the Sons of Solomon's Servants." VT 11/1 (1961): 159-169. https://doi.org/10.1163/156853361X00129.

Hodossy-Takács, Elöd. "Clash and Coexistence in Ancient Palestine.” Pages 343-352 in Ein pralles Leben: Alttestamentliche Studien. Für Jutta Hausmann zum 65. Geburtstag und zur Emeritierung. Edited by Éva P. Verebics, Nikolett Móricz \& Miklós Kőszeghy. Arbeiten zur Bibel und ihrer Geschichte 56. Leipzig: Evangelische Verlangsanstalt, 2017.

Houten, Christiana van. The Alien in Israelite Law. JSOTSup 107. Sheffield: Sheffield Academic Press, 1991.

Jones III, Edward Allen. Reading Ruth in the Restoration Period: A Call for Inclusion. HB/OT Studies 604. New York: T \& T Clark, 2016.

Kalimi, Isaac. "Three Assumptions about the Kenites." ZAW 100/3 (1988): 386-393. https://doi.org/10.1515/zatw.1988.100.3.386.

Kearney, Peter J. "The Role of the Gibeonites in the Deuteronomic History." CBQ 35 (1973): 1-19.

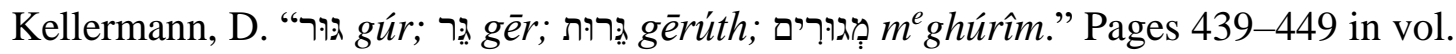
2 of Theological Dictionary of the Old Testament. Edited by G. J. Botterweck \& H. Ringgren. 15 vols. Grand Rapids: Eerdmans, 1975.

Kennedy, Elisabeth R. Seeking a Homeland: Sojourn and Ethnic Identity in the Ancestral Narratives of Genesis. BibInt Series 106. Leiden/Boston: Brill, 2011. https://doi.org/10.1163/ej.9789004191693.i-266.

Knights, Chris H. "Kenites=Rechabites? 1 Chronicles ii 55 Reconsidered." VT 43/1 (1993): 10-18.

Krapf, Thomas M. "Traditionsgeschichtliches zum deuteronomischen FremdlungWaise-Witwe-Gebot.” VT 34/1 (1984): 87-91. https://doi.org/10.1163/156853 384X00098.

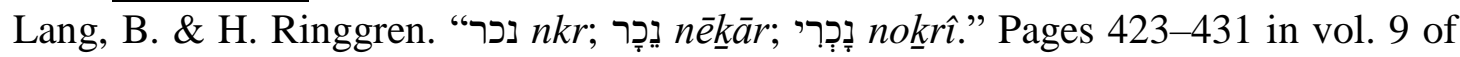
Theological Dictionary of the Old Testament. Edited by G. J. Botterweck, H. Ringgren \& H.-J. Fabry. Grand Rapids: Eerdmans, 1998.

Latvus, K. "From Army Campsite to Partners in Peace: The Changing Role of the Gibeonites in the Redaction Process of Josh. x 1-8; xi 19." Pages 111-115 in "Lasset uns Brücken bauen..." Collected Communications to the XVIth Congress of the International Organization for the Study of the Old Testament, Cambridge 1995. Edited by K.-D. Schunck \& M. Augustin. BEATAJ 42. Frankfurt aM.: Peter Lang, 1998. 
Lemche, Niels P. "From Patronage Society to Patronage Society." Pages 106-120 in The Origins of the Ancient Israelite States. Edited by Volkmar Fritz \& Philip R. Davies. JSOTSup 228. Sheffield: Sheffield Academic Press, 1996.

Leuchter, Mark. "The Cult of Kiriath Yearim: Implications from the Biblical Record." VT 58 (2008): 526-543. https://doi.org/10.1163/156853308X348204.

Leveen, Adriane. "Inside and Out: Jethro, the Midianites and a Biblical Conception of the Outsider." JSOT 34/4 (2010): 395-417. https://doi.org/10.1177/0309089210 365966.

. Biblical Narratives of Israelites and their Neighbours: Strangers at the Gate. RIPBC. London: Routledge/Taylor \& Francis Group, 2017.

Levinson, Bernard M. "Is the Covenant Code an Exilic Composition? A Response to John Van Seters." Pages 272-325 in In Search of Pre-exilic Israel. Edited by John Day. JSOTSup 406. London: T \& T Clark, 2004.

Liver, Jacob. "The Literary History of Joshua IX." JSS 8 (1963): 227-243. https://doi. org/10.1093/jss/8.2.227.

Lozovyy, Joseph. Saul, Doeg, Nabal, and the "Son of Jesse". Readings in 1 Samuel 16-25. HB/OT Studies 497. New York: T \& T Clark, 2011, 51-83.

Matthews, Victor H. \& Don C. Benjamin. Social World of Ancient Israel. 1250-587 BCE. Peabody: Hendrickson, 1993.

Matthews, Victor H. "Herem versus Hospitality in the Story of Rahab." Pages 217-233 in The Genre of Biblical Commentary: Essays in Honor of John E. Hartley on the Occasion of His $75^{\text {th }}$ Birthday. Edited by Timothy D. Finlay \& William Yarchin. Eugene: Wipf \& Stock, 2015.

Mayes, Andrew D. H. "Deuteronomy 29, Joshua 9, and the Place of the Gibeonites in Israel." Pages 321-325 in Das Deuteronomium: Entstehung, Gestalt und Botschaft. Edited by Norbert Lohfink. BETL 68. Leuven: Peeters, 1985.

McNutt, Paula M. "The Kenites, the Midianites, and the Rechabites as marginal mediators in ancient Israelite tradition." Semeia 67 (1994): 109-132.

Miller, J. Maxwell. "The Descendants of Cain: Notes on Genesis 4.” ZAW 86 (1974): 164-174. https://doi.org/10.1515/zatw.1974.86.2.164.

Mondriaan, Marlene E. "Who were the Kenites?" OTE 24/2 (2011): 414-430.

Na'aman, Nadav. "From Conscription of Forced Labour to a Symbol of Bondage: Mas in the Biblical Literature." Pages 746-758 in An Experienced Scribe Who Neglects Nothing: Ancient Near Eastern Studies in Honor of Jacob Klein. Edited by Y. Sefati, P. Artzi, Ch. Cohen, B. L. Eichler \& V. A. Hurowitz. Bethesda: CDL Press, 2005.

. "Sojourners and Levites in the Kingdom of Judah in the Seventh Century BCE." ZAR 14 (2008), 237-279.

—. "The Sanctuary of the Gibeonites Revisited." JANER 9 (2009): 101-124. https://doi.org/10.1163/156921109X12520501747714.

. "The $\gg$ Kenite Hypothesis« in the Light of the Excavations at Horvat 'Uza."

Pages 171-182 in Not Only History: Proceedings of the Conference in Honor of Mario Liverani. Edited by Gilda Bartoloni, Maria G. Biga \& Armando Bramanti; Winona Lake: Eisenbrauns, 2016.

Nicholson, Ernest. "»Do not Dare to Set a Foreigner over You." The King in Deuteronomy and »The Great King«." ZAW 118 (2009): 46-61. https://doi .org/10.1515/ZAW.2006.003. 
Nolan, Gary. The Role of the Kenites in Israel's History. ThD Diss. New Orleans: Baptist Theological Seminary, 1982.

Olyan, Saul M. Rites and Rank: Hierarchy in Biblical Representations of Cult. Princeton: Princeton University Press, 2000. https://doi.org/10.1515/978140082 3567.

Otto, Eckart. "The Study of Law and Ethics in the Hebrew Bible / Old Testament." Pages 594-621 in Hebrew Bible/Old Testament. The History of Its Interpretation. Vol. 3: From Modernism to Post-Modernism (The Nineteenth and Twentieth Centuries). Part 2: The Twentieth Century. Edited by Magne Saebo. Göttingen: Vandenhoeck \& Ruprecht, 2015. https://doi.org/10.13109/9783666540226.594.

Pace, James H. The Caleb traditions and the role of the Calebites in the history of Israel. PhD Diss., Emory University, 1976.

Patterson, Richard D. "The Widow, the Orphan, and the Poor in the Old Testament and the Extra-Biblical Literature." BibSac 130 (1973): 223-234.

Pedersen, Josh. Israel. Its Life and Culture. Vols. I-II; London: Oxford University Press, 1926.

Pfoh, Emanuel. "Some Remarks on Patronage in Syria-Palestine during the Late Bronze Age." JESHO 52/3 (2009): 363-381. https://doi.org/10.1163/156852009X45 $\underline{8197 .}$

. "Metalworkers in the Old Testament: An Anthropological View." Pages 201217 in Methods, Theories, Imagination: Social Scientific Approaches in Biblical Studies. Edited by D. J. Chalcraft, F. Uhlenbruch \& R. S. Watson. The Bible and Social Science 1. Sheffield: Sheffield Phoenix Press, 2014.

Pitkänen, Pekka. "Ancient Israelite Population Economy: Ger, Toshav, Nakhri and Karat as Settler Colonial Categories." JSOT 42/2 (2017): 139-153. https://doi.org /10.1177/0309089216677665.

Ramírez Kidd, José E. Alterity and Identity in Israel: The 7 in the Old Testament. BZAW 283. Berlin/New York: Walter de Gruyter, 1999. https://doi.org/10.151 5/9783110802221.

Rendtorff, Rolf: "The gēr in the Priestly Laws of the Pentateuch." Pages 77-87 in Ethnicity and the Bible. Edited by Mark G. Brett. BibInt Series 19. Leiden/New York/Köln: Brill, 1996.

Riegner, Irene E. The Vanishing Hebrew Harlot: The Adventures of the Hebrew Stem ZNH. Studies in Biblical Literature 73. Bern: Peter Lang, 2009. https://doi.org/ 10.3726/978-1-4539-0284-4.

Robinson, Bernard P. "Rahab of Canaan —and Israel." SJOT 23/2 (2009): 257-273. https://doi.org/10.1080/09018320903303603.

Roi, Micha. "To This Day: Aetiology, Rhetoric, or Literary Motif?” SJOT 27/2 (2013): 285-295. https://doi.org/10.1080/09018328.2013.856074.

Rösel, Hartmut N. "Anmerkungen zur Erzählung vom Bundesschluss mit den Gibeoniten.” BN 28 (1985): 30-35.

Schäfer-Lichtenberger, Christa. "Das gibeonitische Bündnis im Lichte deuteronomischer Kriegsgebote: Zum Verhältnis von Tradition und Interpretation in Jos 9." BN 34 (1986): 58-81.

Schloen, J. David. "Caravans, Kenites, and Casus Belli: Enmity and Alliance in the Song of Deborah." CBQ 55 (1993): 18-38.

Seters, J. Van. A Law Book for the Diaspora: Revision in the Study of the Covenant Code. Oxford/New York: Oxford University Press, 2003. 
. "David and the Gibeonites." ZAW 123/4 (2011): 535-552. https://doi.org/10.1 515/ZAW.2011.035.

Sneed, Mark. "Israelite Concern for the Alien, Orphan, and Widow: Altruism or Ideology?" ZAW 111/4 (1999): 498-507. https://doi.org/10.1515/zatw.1999.111 .4 .498 .

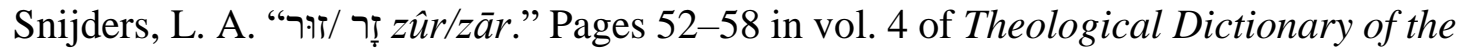
Old Testament. Edited by G. J. Botterweck \& H. Ringgren. 15 vols. Grand Rapids: Eerdmans, 1980.

Southwood, Katherine E. Ethnicity and the mixed marriage crisis in Ezra 9-10. Oxford Theological Monographs. Oxford: Oxford University Press, 2012. https://doi.org /10.1093/acprof:oso/9780199644346.001.0001.

Spina, Frank A. 'Israelites as gērim, 'Sojourners,' in Social and Historical Context." Pages 321-335 in The Word of the Lord Shall Go Forth: Essays in Honor of David Noel Freedman in celebration of his $60^{\text {th }}$ birthday. Edited by Carol L. Meyers \& M. P. O'Connor. ASOR Special Volume Series 1. Winona Lake: Eisenbrauns, 1983.

- The Faith of the Outsider: Exclusion and Inclusion in the Biblical Story. Grand Rapids/Cambridge: Eerdmans, 2005.

Stander, H. F. "The Greek Church Fathers and Rahab." Acta Patristica et Byzantina 17 (2006): 37-49. https://doi.org/10.1080/10226486.2006.11745767.

Stansell, Gary. "Wealth: How Abraham Became Rich." Pages 92-110 in Ancient Israel: The Old Testament in its Social Context. Edited by Philip F. Esler. Minneapolis: Fortress Press, 2005.

Sutherland, Ray K. "Israelite Political Theories in Joshua 9." JSOT 53 (1992): 65-74. https://doi.org/10.1177/030908929201705304

Toczyski, Andrzej. The 'Geometrics' of the Rahab Story: A Multi-Dimensional Analysis of Joshua 2. HB/OT Studies 664. New York: T \& T Clark, 2018.

Toorn, Karel van der. "Ritual Resistance and Self-assertion: The Rechabites in Early Israelite Religion." Pages 229-259 in Pluralism and Identity: Studies in Ritual Behaviour. Edited by Jan Platvoet \& Karel Van der Toorn; Studies in the History of Religions 67. Leiden: Brill, 1995.

Versluis, Arie. The Command to Exterminate the Canaanites: Deuteronomy 7. OTS 71. Leiden: Brill, 2017. https://doi.org/10.1163/9789004341319.

Westbrook, Raymond. "Patronage in the ancient Near East." JESHO 48/2 (2005): 210 233. https://doi.org/10.1163/1568520054127121.

Wright, Jacob L. David, King of Israel, and Caleb in Biblical Memory. Cambridge: Cambridge University Press, 2014. https://doi.org/10.1017/CBO9781107449 $\underline{749}$.

- "Rahab's Valor and the Gibeonites' Cowardice." Pages 199-211 in Worship, Women and War: Essays in Honor of Susan Niditch. Edited by John J. Collins, T. M. Lemos \& Saul M. Olyan. Brown Judaic Studies 357. Atlanta: SBL Press, 2015.

Wuench, Hans-Georg. "The Stranger in God's Land - Foreigner, Stranger, Guest: What Can We Learn from Israel's Attitude towards Strangers?" OTE 27/3 (2014): 1129-1154.

Zakowitch, Y. "Rahab als Mutter des Boas in der Jesus-Genealogie (Matth. I 5)." NovT 17/1 (1975): 1-5. https://doi.org/10.1163/156853675X00077. 
154 Jenei, "Strategies for Stranger Inclusion," OTE 32/1 (2019): 127-154

Zehnder, Markus. Umgang mit Fremden in Israel und Assyrien: Ein Beitrag zur Anthropologie des »Fremden « im Licht antiker Quellen. BWANT 168. Stuttgart: Kohlhammer, 2005.

Zeydner, H. "Kainszeichen, Keniter und Beschneidung." ZAW 18/1 (1898): 120-125. https://doi.org/10.1515/zatw.1898.18.1.120.

Zyl, A. H. van. "The Relationship of the Israelite Tribes to the Indigenous Population of Canaan according to the Book of Judges." Pages 51-60 in Studies on the Book of Judges: Papers read at 2rd meeting held at Potchefstroom, 2-5 February 1959. Pretoria: OTWSA, 1959.

"Israel and the Indigenous population of Canaan according to the Book of Samuel." Pages 67-80 in Studies on the Books of Samuel: Papers read at $3^{\text {rd }}$ meeting held at Stellenbosch, 26-28 January 1960. Pretoria: OTWSA, 1960.

Dr Péter Jenei, Postdoctoral Fellow, Department of Old Testament Studies, University of Pretoria. Email: peter.jenei83@gmail.com. ORCID: https://orcid.org/0000-0002-0491-4171. 